Vol.45, Special n. : pp. 125-133, September 2002 ISSN 1516-8913 Printed in Brazil

\title{
Two Decades of Radiological Accidents Direct Causes, Roots Causes and Consequences
}

\author{
Jose de Julio Rozental* \\ Radiation Safety and Regulation; joseroze@netvision.net.il; Rehov Hartzit 31; Natania South; 42490; Israel
}

\begin{abstract}
Practically all Countries utilize radioisotopes in medicine, industry, agriculture and research. The extent to which ionizing radiation practices are employed varies considerably, depending largely upon social and economic conditions and the level of technical skills available in the country. An overview of the majority of practices and the associated hazards will be found in the Table IV to VII of this document. The practices in normal and abnormal operating conditions should follow the basic principles of radiation protection and the Safety of Radiation Sources, considering the IAEA Radiation Protection and the Safety of Radiation Sources, Safety Series 120 and the IAEA Recommendation of the Basic Safety Standards for Radiation Protection, Safety Series $N^{o} 115$. The Standards themselves underline the necessity to be able to predict the radiological consequences of emergency conditions and the investigations that should need to be done. This paper describes the major accidents that had happened in the last two decades, provides a methodology for analyses and gives a collection of lessons learned. This will help the Regulatory Authority to review the reasons of vulnerabilities, and to start a Radiation safety and Security Programme to introduce measures capable to avoid the recurrence of similar events. Although a number of accidents with fatalities have caught the attention of the public in recent year, a safety record has accompanied the widespread use of radiation sources. However, the fact that accidents are uncommon should not give grounds for complacency. No radiological accident is acceptable. From a radiation safety and security of the sources standpoint, accident investigation is necessary to determine what happened, why, when, where and how it occurred and who was (were) involved and responsible. The investigation conclusion is an important process toward alertness and feedback to avoid careless attitudes by improving the comprehension of Safety Performance and Safety Culture. Accident investigation is the first step toward avoiding future injures and financial losses, by prevention of recur recurrence. On the other hand, accident investigation is also essential for the establishment of the responsibilities and liability for the consequences. This document discuss the main accidents that have happened in the last two decades, in terms of causes, consequences, similarities and lessons learned when sealed sources have been damaged, lost, stolen and abandoned. In considerable majority death and serious injuries were resulted from failures in the safety system for radiation sources and for the security of radioactive materials.
\end{abstract}

Key words: Radiological accidents, direct causes, roots causes, radiation protection, Safety of Radiation Sources, Safety Culture

\footnotetext{
* Author for correspondence
} 


\section{INTRODUCTION}

Nevertheless all radiation-safety and security precautions, Incidents or accidents have happened when sealed sources have been damaged, lost, stolen, or abandoned. In large majority death and serious injuries were resulted from failures in the safety system for radiation sources and for the security of radioactive materials. It is necessary also to mention many incidents or even accidents due the mismanagement of medical practices, using unsealed sources. However, in the preponderance of these cases, the roots are associated with human errors, as the accidents cited in the Table 1 and 2 .

\section{MATERIAL AND METHOD}

Based on the International Atomic Energy Agency publications, referenced.

Table 1 - Radiological Accidents Fatalities 1981/2000.

\begin{tabular}{|c|c|c|c|c|}
\hline \multirow[t]{2}{*}{ YEAR } & \multirow[t]{2}{*}{ LOCATION } & \multirow[t]{2}{*}{ APPLICATION } & \multicolumn{2}{|c|}{ FATALITIES } \\
\hline & & & WORKERS & PUBLIC \\
\hline 1981 & Oklahoma, USA & Industrial Radiography & 1 & \\
\hline 1982 & Kjeller, Norway & Irradiation Facility & 1 & \\
\hline 1984 & Morocco & Lost of source $\mathrm{Ir}-19230 \mathrm{Ci}$ & & 8 \\
\hline 1987 & Goiania, Brazil & Teletherapy Device & & $4(1)$ \\
\hline 1989 & San Salvador & Irradiation Facility & 1 & \\
\hline 1990 & Israel & Irradiation Facility & 1 & \\
\hline 1990 & Zaragoza, Spain & Linear Accelerator & & $11(2)$ \\
\hline 1991 & Nesvizh, Belarus & Irradiation Facility & 1 & \\
\hline 1992 & Xinzhou, China & Lost of Co-60 source & & $3(3)$ \\
\hline 1992 & Indiana, USA & Ir-192 (3.7 Ci) brachytherapy & & $1(4)$ \\
\hline 1994 & Tammiku, Estonia & Abandoned Scrap Cs 137 & & 1 \\
\hline 1996 & Costa Rica & Co-60 Teletherapy & & $7(5)$ \\
\hline 2000 & Thailand & Lost Co-60 (420 Ci) & & $3(6)$ \\
\hline 2000 & Egypt & Lost Ir-192 (20 Ci) & & $2(7)$ \\
\hline Aug/2000 & Panama & Co-60 Teletherapy & & $5(8)$ \\
\hline $\mathrm{Feb} / 2001$ & & & & \\
\hline TOTAL & & & 6 & 45 \\
\hline
\end{tabular}

(1) 128,000 people were monitored, 244 persons to be contaminated 54 seriously enough to be hospitalized for further tests or treatment, doses up $7 \mathrm{~Gy}$. Thirty-four were treated and released.

(2) 27 overexposed

(3) 8 over exposed dose $0.25-10$ Gy (local)

(4) Mismanagement survey of the patient after-treatment, source 90 hours in the woman, dose 1000 Gy http:/www.nrc.gov/NRC/COMMISSION/TRANSCRIPTS/19930208a.html

November 16, 1992 -

(5) 115 patients being treated for neoplasm by radiotherapy was affected - Within 9 months of the accident, 42 of the patients died, it appears that 3 may have died as a direct result of overexposure and another 4 were considered to have died with radiation overexposure probably a major contributory cause of death.

(6) A accident 24/25 January 2000 - Source Co-60, Activity 15.5 TBq (420 Ci)

Number of people exposed 10 - Doses: 1 was not precise. 1 around 10 Gy, 4 around 6 Gy 3 around 2 Gy, 1 less than 1 Gy Number of people residents around 450 - Blood examination hairless

(7) Accident 5 May 2000 resident found a source, 2 deaths - High doses 150/200 (Dose 25 to $150 \mathrm{mSv}$ )

(8) From August 2000 to February 2001, due to a calculation error in the data entry of the treatment plan, the patients were treated with a dose $100 \%$ higher than the regular dose. 28 patients being treated for neoplasm by radiotherapy was affected The IAEA team was informed that, of the 28 patients concerned, eight have since died; and the team confirmed that five of these deaths are probably attributable to the patients overexposure to radiation. Of the other three deaths, one is considered to have been related to the patients' cancer; while there was insufficient information available to draw conclusions in respect of the other two deaths. Of the surviving 20 patients, most injuries are related to the bowel, with a number of patients suffering persistent bloody diarrhea, necrosis (tissue death), ulceration and anemia. About three-quarters of the surviving 20 patients may be expected to develop serious complications, which in some cases may ultimately prove fatal. http://www.iaea.or.at/worldatom/Press/P_release/2001/panam_adv_info2.shtml. 19 died until June 27,2002, according with press information. http://mensual.prensa.com/mensual/contenido/2002/06/25/hoy/portada/608821.html 
Table 2 - Radiological Accidents Over-Exposure 1980/2000

\begin{tabular}{|c|c|c|c|}
\hline YEAR & LOCATION & APPLICATION & PUBLIC \\
\hline 1980 & USSR & Irradiation Facility, Co-60 - 50 Gy (local. Legs) & 1 \\
\hline 1980 & GDR & X-Ray, 15-30 Gy - hand & 1 \\
\hline 1980 & FRG & Radiography 23 Gy hand & 1 \\
\hline 1980 & China & Co-60 60.5 Gy local, 15-30 Gy - hand & 1 \\
\hline 1981 & Saintes, France & Co-60, Medical, 25 Gy & 3 \\
\hline 1981 & Oklahoma, USA & Ir-192 (dose unknow) & 1 \\
\hline 1982 & Norway & Co-60 22 Gy (1 death) & 1 \\
\hline 1982 & India & Ir-192 35 Gy Local & 1 \\
\hline 1983 & México & Co-60-450 Ci $0.25-5.0$ Gy (protracted exposure) & 10 \\
\hline 1983 & Iran & Itr-192, 20 Gy hand & 1 \\
\hline 1984 & Marocco & Ir-192 (8 death) & 11 \\
\hline 1984 & Peru & X-Ray $(5-40$ Gy) local & 6 \\
\hline 1985 & China & Electron Accelerator Unknown local & 2 \\
\hline 1985 & China & Au-198 Mistake in treatment Unknown, internal (2 death) & 9 \\
\hline 1985 & China & Cs-137 8 - 10 Sv Subacute & 3 \\
\hline 1985 & Brazil & $\begin{array}{l}\text { Ir-192 Radiography Up to } 410 \text { Gy Finger and left hand (2 } \\
\text { workers) }\end{array}$ & 1 \\
\hline 1985 & Brazil & Ir-192 Radiography Up 160 Gy hand & 18 \\
\hline $1985 / 86$ & USA & Accelerator (2 death) & 3 \\
\hline 1986 & China & Co-60 $2-3$ Gy & 2 \\
\hline 1987 & China & Co-60 1.0 Gy & 1 \\
\hline 1987 & China & Co-60 1.0 Gy & 1 \\
\hline 1989 & India & Ir-192 $20-50$ Gy hands & \\
\hline 1991 & USA & Accelerator 30 Gy hands \& legs & 1 \\
\hline 1992 & Vietnam & Accelerator 8.8 Gy fingers & 1 \\
\hline 1996 & Gilan, Iran & Ir-192 radiography $2-3$ Gy (whole Body) & 1 \\
\hline 1997 & Lilo, Georgia & $\begin{array}{l}\text { Several sources of caesium-137 and cobalt- } 60 \text { of various } \\
\text { activities (Max. Cs-137, } 4 \mathrm{Ci}-\text { (Victims, irradiated for about } 1 \\
\text { year) }\end{array}$ & 11 \\
\hline 1998 & Turkey & Co-60 Various doses, up to 3 Gy whole body & 10 \\
\hline 1999 & Peru & $\begin{array}{l}\text { Lost of source Ir-192 radiography up to } 100 \text { Gy locally, leg } \\
\text { amputation (Ir-192 } 26 \mathrm{Ci} \text { ) }\end{array}$ & 1 \\
\hline
\end{tabular}

International Atomic Energy Agency (1991) mention the occurrence of more than 100 reported accidents with sealed radiation sources involving about 700 persons over-exposed to whole body dose larger than $0.25 \mathrm{~Sv}$ or to a local skin dose above $6 \mathrm{~Sv}$. In addition there have bee $n$ accidents with sealed or unsealed sources that were not reported, in number probably equally large. Dicus, G. H. (1999) and in http://www.newsteel.com/ features/NS9712WA.htm, mention that 200 radioactive sources and devices containing radioactive materials regulated under the Atomic Energy Act are either lost, stolen, or abandoned and have entered the public domain in an uncontrolled manner, an NRC report says. In 1983-1996 there were 25 confirmed accidental melting of radioactive sources at U.S. mills. Disposal and cleanup cost plant owners an average of $\$ 10$ million; at one mill where a melting occurred, it cost up to $\$ 23$ million.

We could add situations of concern due the cases of accidental melting of radioactive materials and damage to property in the form of radioactive contamination that have been occurred when metal recycling industry when radioactive sources that had occurred, when lost, stolen, or abandoned radioactive sources become mixed with metal scrap destined for recycling (Gonzales, A. J., 1999).

The main reason for the worst radiological accident in the world, the radiological accident in Goiania and the accidents mentioned in Table 1 and 2 and probably the great majority (The Radiological Accident in Goiania, 1988; Accidental Overexposure of Radiotherapy Patients in San Jose, 1998; The Radiological Accident in San Salvador, 1990; The Radiological Accident in 
Soreq, 1993; An Electron. Accelerator Accident in Hanoi, 1996; The Radiological Accident at the Irradiation Facility In Nesvizh, 1996; The Radiological Accident in Tammiku, 1998; Lessons Learned from Accidents in Industrial Irradiation Facilities, 1996; Lessons Learned from Accidents in Industrial Radiography, 1998), were frequent workers' errors, some of them illogical and similar. These lessons learned, has proved a lack of "Safety Culture and Human Behavior" and "Safety Culture and Information Dissemination" among personnel, organization and competent authorities. This applies mostly to those countries, without any or little infrastructure. However, the last remark does not exclude developed country, as we can understand from several radiological accidents and nuclear accidents, reported in the literature (IAEA Bulletin, 1999).

To have an idea on this situation it is interesting to read the Medical Basis For Accident Preparedness (Hubner, K. F. and Fry, S. A., 1979).

\section{Connection: Radiological Accident x Reasons of Deficiencies}

Considering the above assumption, it's possible to relate the radiological abnormal events as in direct connection with the deficiencies in one or more of the essential fundamental basis of Radiation Safety and Security, as shows in the following diagram.

\section{ROOTS OF RADIOLOGICAL ACCIDENTS- DEFICIENCES ON:}

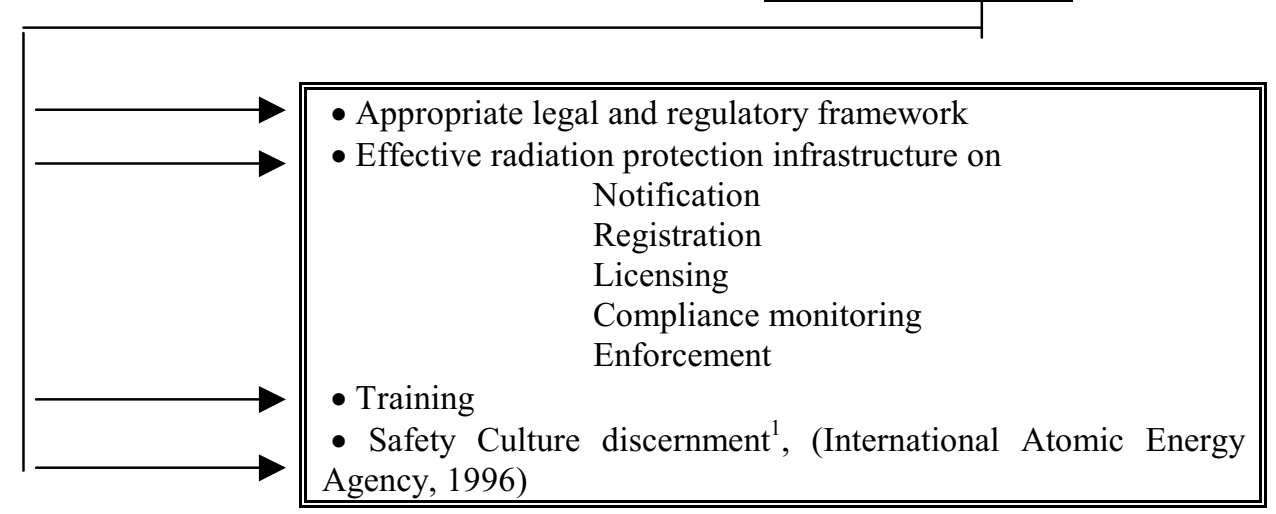

Safety Culture discernment, positively is the main point of convergence to help in the implementation of legislation, regulation, human and material resources and adequate control and procedures for good practice.

\section{RESULTS AND DISCUSSION}

\section{Sources of most concern in case of accidents}

Cs-137 old sources, manufactured to standards lower than would be justifiable in the present. The radioactive substance in form of powder or salt can be readily dispersed if the encapsulation could be damaged;

Ra-226 sources, always accompanied by its daughter products, containing both alpha, highenergy beta and high-energy gamma radiation. Ra226 sources do not survive fire, as they would rupture because of internal overpressure created during fire;

Am-241 sources, like Cs-137 is a by-product of nuclear power production, has chemical characteristics similar to the rare earth metals, indicating that as metal it is not in a stable form. Normally oxides are used in sources. Its half-life is 433 years and it decays by alpha emission to a long-lived neptunium isotope, with a half-life of 2 million years. The Am-241/Be source used in well logging prospecting reach activity up $800 \mathrm{GBq}$; Sr-90 sources, half-life 28 years, is also a fission product in reactor fuel and as oxides are used in the Sr-90/Y-90 sources. The high-energy beta of the daughter product Yttrium-90, results in the emission of high-energy bremsstrahlung, which may require heavy shielding for high strength sources;

Co-60 sources, half life 5.3 years, in Industrial Radiography reaches activity up $5 \mathrm{TBq}$, in average, $1 \mathrm{TBq}$ and as teletherapy unit and food irradiation/sterilization unit $400 \mathrm{TBq}$ and $80 \mathrm{PBq}$, respectively. Co-60 is also used both as manual 
brachytherapy, range of activity 50 - $500 \mathrm{MBq}$ and after loading brachyherapy, activity up to $10 \mathrm{GBq}$; Ir-192 sources, half-life 74 days, in Industrial Radiography reach activity up $8 \mathrm{TBq}$, in average, $4 \mathrm{TBq}$ and as remote after loading brachytherapy an activity up $400 \mathrm{GBq}$. In both case s the main use is as mobile units.

Radiological accident taking into account the practice, effect of hazard and consequences, can be group according Tables 4, 5 and 6.

Table 3 - Basic Data

\begin{tabular}{|c|c|c|c|c|c|}
\hline CHARACTERISTICS & Co-60 & Cs-137 & Ir-192 & Am-241 & $\operatorname{Ra}^{226}{ }^{1}$ \\
\hline Half life & $5.26 \mathrm{y}$ & $30 \mathrm{y}$ & $74 \mathrm{~d}$ & $433 \mathrm{y}$ & $1600 y$ \\
\hline Energy Mev & & & & & \\
\hline alfa & 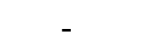 & & & 5.86 & $\mathrm{obs}^{2}$ \\
\hline beta (Max) & 0.31 & 1.2 & 0.67 & . & $\mathrm{obs}^{8}$ \\
\hline gamma & $1.17 / 1.33$ & 0.66 & 0.468 & 0.060 & $\mathrm{obs}^{8}$ \\
\hline Dose rate $\frac{\mathrm{Sv} \cdot \mathrm{m}^{2}}{\mathrm{TBq} \cdot \mathrm{h}}$ & 0.351 & 0.081 & 0.13 & $\mathrm{obs}^{3}$ & 0.223 \\
\hline HVL of lead (mm) & 12 & 6 & 5.5 & 0.2 & 14 \\
\hline
\end{tabular}

${ }^{1}$ Still used in many developing countries, and a question of major concern in case of old sources out of standards, or spent sources that should be collected or even abandoned.

${ }_{2}^{2}$ In the decay chain there are alpha energies up to $7.7 \mathrm{Mev}$, beta energies up to $2.8 \mathrm{Mev}$ and main gamma energies up to $2.4 \mathrm{Mev}$

${ }^{3}$ Dose rate is very dependent on encapsulation, which may include a thin window. At short distances the dose rates can be very high from alpha and beta radiation, but not at larger distances

$\underline{\text { Table } 4 \text { - Industrial Sources }}$

\section{PRACTICES}

Industrial Site Radiography

Industrial Radiography in fixed installation with radioactive sources exceeding $1 \mathrm{TBq}$, and $\mathrm{X}$ ray generators exceeding $400 \mathrm{kV}$

$\beta$ and $\gamma$ Gauges and neutron thermalization. Sources should be limited to not more than equivalent 40 $\mathrm{GBq}$ (1 Ci) of Cesium-137 and $40 \mathrm{GBq}$ (1 Ci) Americium-241 or $0.1 \mu \mathrm{g}$ of Californium-252

$\gamma$ Gauges and neutron thermalization using sources exceeding equivalent 40 $\mathrm{GBq}$ (1 Ci) of Cesium-137 and $40 \mathrm{GBq}$ (1 Ci) Americium-241 or $0.1 \mu \mathrm{g}$ of Californium-252

Industrial and research irradiation facilities using sources not exceeding 4 TBq (100 Ci)

Industrial and research irradiation facilities using sources exceeding $4 \mathrm{TBq}$ $(100 \mathrm{Ci})$

\section{CATEGORY \\ OF HAZARD}

3

2

Potential of deterministic health

effects to public in case of lost/stolen

2

2 Potential deterministic health effects to workers

3

Deterministic health effects to workers; Deterministic health effects to public in case of lost/stolen

Deterministic health effects to workers

Higher potential of deterministic health effects to public in case of lost/stolen

Deterministic health

effects to workers 
Table 5 - Medical Sources

\begin{tabular}{|c|c|c|}
\hline MAIN ACTIVITIES & $\begin{array}{l}\text { CATEGORY } \\
\text { OF HAZARD }\end{array}$ & HAZARD \\
\hline Beam Therapy & 3 & Potential deterministic \\
\hline Accelerators and neutron generators & 3 & health effects to \\
\hline Brachytherapy & 3 & workers and patients \\
\hline $\begin{array}{l}\text { Unsealed Sources for Therapeutic } \\
\text { Treatment }\end{array}$ & 3 & $\begin{array}{l}\text { No potential for releases in excess of urgent } \\
\text { level GILs }\end{array}$ \\
\hline Diagnosis & 1 & $\begin{array}{l}\text { Potential risk to Patient; } \\
\text { no potential risk to worker or public }\end{array}$ \\
\hline
\end{tabular}

Table 6 - Manufacturing and Research

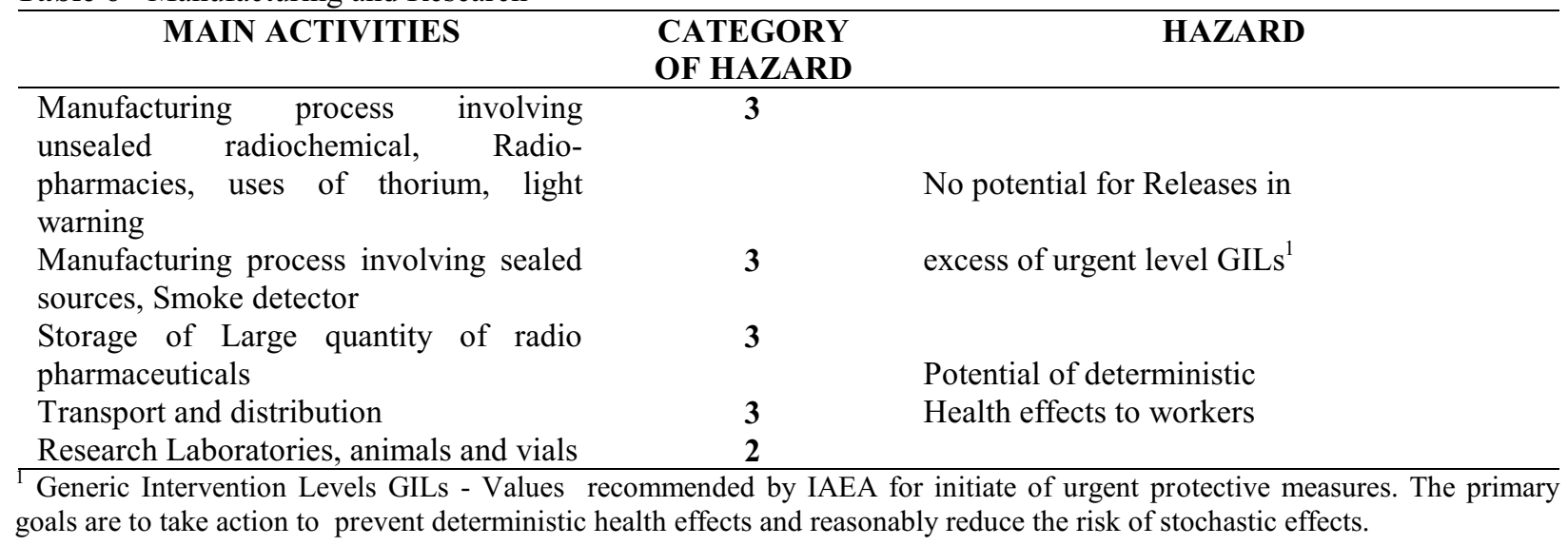

Table 7 - Categories of Hazard

\begin{tabular}{l} 
CATEGORY \\
\hline $\mathbf{0}$ \\
$\mathbf{1} \begin{array}{l}\text { CHARACTERISTICS } \\
\text { Low routine dose; low risk of significant contamination; low public health risk from worst } \\
\text { accidents, normally with no consequences for public exposure. Health risk for patient in case } \\
\text { of misadministration } \\
\text { Low routine dose; some risk of minor contamination; possibility of some health effects with } \\
\text { worst-case emergencies, but negligible risk for public exposure. }\end{array}$ \\
Low to high routine dose; risk of significant contamination; potential for prompt health \\
effects from worst-case emergencies, with potential for public exposure.
\end{tabular}


The first investigation question is "what happened" and then the following questions should be determinate: why it happen ed? - When, where, how and who was or were responsible. The investigation must be accurate, to public creditability. The media and public frequently ask question on responsibilities, especially in case of damage, injures and fatalities.

\section{Graph to Assess the Accidents reasons and investigation}

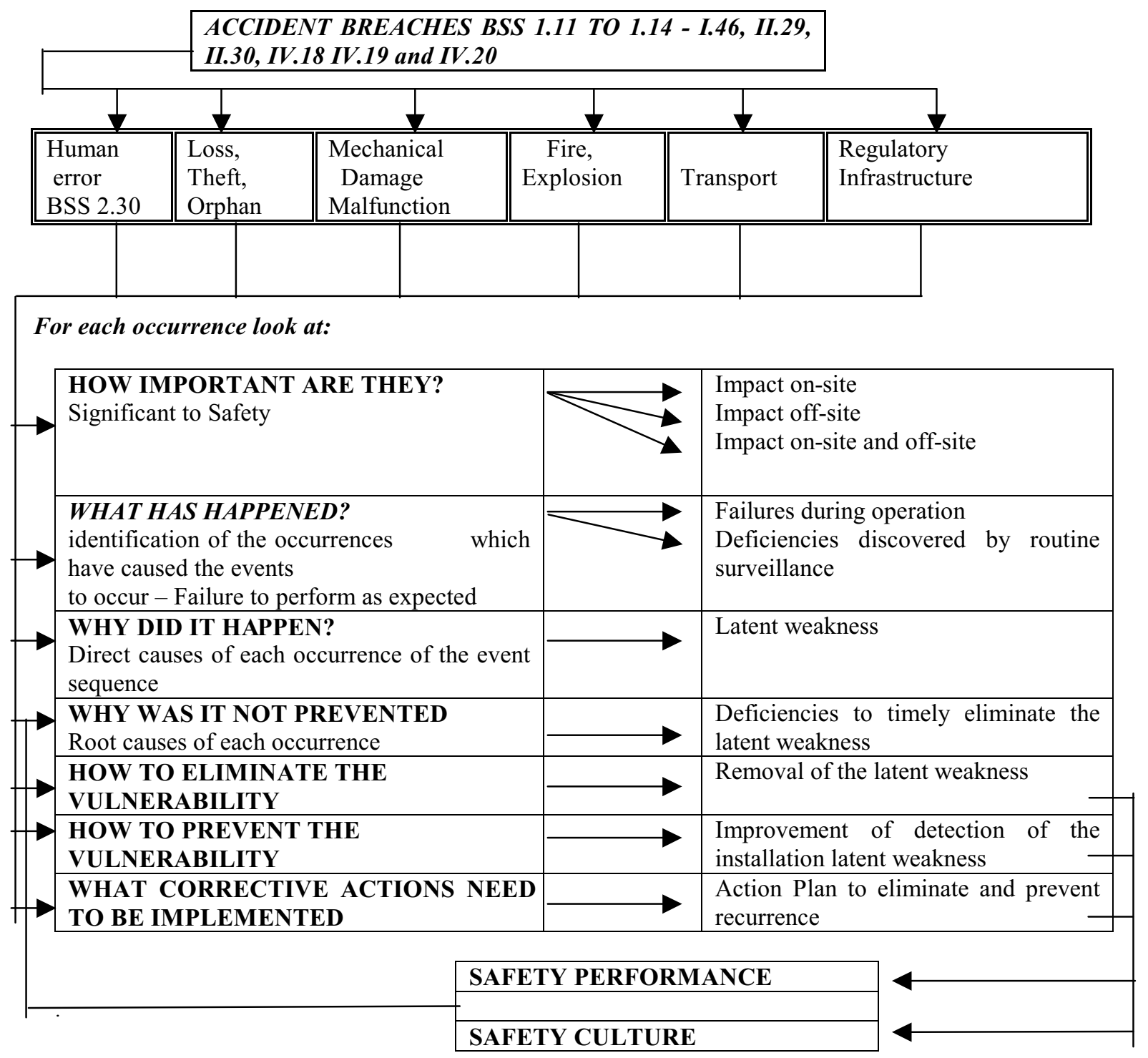

Lessons learned

This document was intended to cover selected topics on the two decades of radiological accidents $1981 / 2000$, that were caused by radiation safety failures, some of which have lead to serious consequences, including the death of some exposed persons. Dissemination and the exchange of information on the lessons learned will help to increase the safety of radiation sources and so reduce the potential of accidents. Regulatory
Authorities can improve their $\mathrm{n}$ ational system for the control of radiation sources by applying these lessons. Manufacturers and users can also efficiently contribute to the prevention of such accidents. An extensive information on lessons learned can be studied in the IAEA documents (The Radiological Accident in Goiania, 1988; Accidental Overexposure of Radiotherapy Patients in San Jose, 1998; The Radiological Accident in 
San Salvador, 1990; The Radiological Accident in Soreq, 1993; An Electron. Accelerator Accident in Hanoi, 1996; The Radiological Accident at the Irradiation Facility In Nesvizh, 1996; The Radiological Accident in Tammiku, 1998; Lessons Learned from Accidents in Industrial Irradiation Facilities, 1996; Lessons Learned from Accidents from Accidents in Industrial Radiography, 1998). However, it is important to take in high level that, besides hundreds of lessons learned that four fundamental lessons stand out:

- Implausible Accident can happen suddenly when least expected;

- Accident caught countries by surprise!

- Emergency Planning and Preparedness is still in an incipient stage in those developing countries with little infrastructure, which applies to about $50 \%$ of the IAEA's Member;

- Many lessons of the previous accident were identified, however not yet completely learned.

The International Conference jointly org anized by the EC, IAEA, Interpol and WCO and held in Dijon, France, 14-18 September 1998, brought to light several new vectors with the aim to formulate an effective international operation of national systems for ensuring the safety of radiation sources and the security of radioactive materials. The Resolution adopted on 25 September 1998 during the 10th plenary meeting (http://www.iaea.org/GC/gc42/resolutions/gc42res 12.html) emphasized the principal subjects toward effective measures against illicit trafficking in nuclear materials and other radioactive sources, as well as to encourages all governments to take steps to ensure the existence within their territories of effective national systems of control for ensuring the safety of radiation sources and the security of radioactive materials.

Today many National Authorities, specially USA, has been reporting serious accidents linked to breaches in safety of radiation sources, due several reasons, especially the cases of abandoned, lost or outside the regulatory authority control, case of the so called orphan sources.

To avoid the types of accidents that have happened in recent years Regulatory Authority needs to start with legislation to improve regulations and basic resources necessary to establish an effect ive regulatory programme to achieve safety and security goals in a manner compatible with national resources and needs, diagram 1 . The next step is to start with a broad analyze of the roots and the consequences of these abnormal events, like described in this document, to establish the necessary changes in the direction of effe ctively to implement measures to prevent breaches in the security of radioactive materials (from production to disposal) (According 1.11 to 1.14 of the IAEA BSS). In this step, the first attitude should to prepare a comprehensive report reviewing the nature and background of the problem, also giving an overview of existing practices in the country for the management of spent radiation sources.

Basically Regulatory Authority should take into consideration the following aspects:

1. Inspection Programme to identify possible orphan sources (lost, abandoned and outside of regulatory authority control)

2. Inspection of all metal recycling industries and junkyard to explain recent cases and stimulate owners to introduce a system of radioactive detection, to effective control the possibility to receive an orphan source

3. Administrative review to:

- Geographical Identification of all radioactive sources used in the Country in the different practices;

- Geographical location of licensee's interim storage for sources not in use at the moment;

- Programme of lectures to feedback lessons learned from the accidents and to implement the concept of Safety Culture and Human Factors;

- Collection, transport and disposal of all spent sources in the country;

- Return of sources to suppliers, whenever possible.

4. Point of optimum contact

- Intensive connection with Customs to explain the necessity of joint effort in this direction.

- Inform adequately other Competent Authorities in the Country, as ministry of Health, Labor, Transport, Environment and Center for Training in Radiation Safety about the objectives and conclusions of the Conference in Dijon for an ample operational attitude 


\section{RESUMO}

Materiais radioativos encontram-se em todos os paises para as mais diferentes atividades nos campos da industria, medicina, agricultura, veterinária e pesquisa. São transportados milhares de fontes, via área, superfície ou marítima. Assim, pode-se prever situações de emergência nos casos em que acidentes possam ocorrer. Por outro lado, ainda e incipiente o controle de fontes em mais da metade dos paises membros da AIEA, conforme se comprova no mais recente press release dessa Organização Internacional "Vienna, 24 June 2002 - "Mais de 100 paises possuem inadequado controle de programa de monitoração necessário para prevenir ou mesmo detectar roubos desses materiais", conforme o IAEA SITE: http://www.iaea.org/worldatom/Press/P_release/20 02/prn0209.shtml

$\mathrm{O}$ presente trabalho procura mostrar os acidentes com fatalidades e super-exposição nas duas ultimas décadas, bem como suas conseqüências e razões. É um alerta para as Autoridades Competentes que devem procurar atualizar com legislação adequada, recursos básicos materiais e humanos e um sistema de sanção, para casos que investigações assim conclua.

\section{REFERENCES}

Accidental Overexposure of Radiotherapy Patients in San Jose, Costa Rica, IAEA REF: STI/PUB/1027, 1998.

An electron. Accelerator accident in hanoi, VIET NAM, IAEA Ref STI/PUB/1008, 1996.

Dicus, G. H. (1999), Safety \& Security of Radioactive Sources in the United States. IAEA Bulletin, 41 : (3).
Gonzales, A. J. (1999), Strengthening Radiation Safety and Security. IAEA Bulletin, 41 : (3).

Http://www.newsteel.com/features/NS9712WA.htm.

Hubner, K. F.; Fry, S. A. (1979), The Medical Basis For Accident Preparedness. In- Clinical Course and Dosimetry of acute hand injures to Industrial Radiographers from multicurie sealed gamma sources. Elsevier/North Holland. pp. 173.

IAEA Bulletin (1999), 41 : (3).

International Atomic Energy Agency, Basic Safety Standards for Radiation Protection, IAEA Safety Series, nº 115, Vienna, 1996.

International Atomic Energy Agency, Nature and magnitude of the problem of spent radiation sources, IAEA-TECDOC-620, Vienna, 1991.

International Atomic Energy Agency, Radiation Protection and the Safety of Radiation Sources, Safety Series, nº 120, Vienna, 1996.

International Atomic Energy Agency, The Safety of Nuclear Installations, IAEA Safety Series, nº 110, Vienna, 1993.

Lessons Learned from Accidents from Accidents in Industrial Radiography, Safety Report Series, $\mathrm{n}^{\mathbf{0}}$ 7, IAEA 1998.

Lessons Learned from Accidents in Industrial Irradiation Facilities: STI/PUB/1015, Vienna, 1996.

The Radiological Accident at the Irradiation Facility in Nesvizh, IAEA Ref STI/PUB/1010, 1996.

The Radiological Accident in Goiania, IAEA REF: STI/PUB/815, 1988.

The Radiological Accident in Istambul, IAEA REF: STI/PUB/1102, 2000.

The Radiological Accident in San Salvador, IAEA Ref STI/PUB/847, 1990.

The Radiological Accident in Soreq, IAEA Ref STI/PUB/925, 1993).

The Radiological Accident in Tammiku, IAEA REF: STI/PUB/1053, 1998.

The Radiological Accident in Yanango, IAEA REF: STI/PUB/1101, 2000. 